\title{
RECUPERAREA PRUDENTĂ A ORAȘULUI ÎN LOCUIREA COLECTIVĂ Hermeneutică antologică între trei concepte: post-funcționalism, istoricism și formalism/
}

\author{
PRUDENT RECOVERY OF THE CITY IN THE COLLECTIVE DWELLING \\ Anthological Hermeneutics between Three Concepts: Historicism, Formalism and Post- \\ Functionalism
}

Cosmin CACIUC, conf. dr. arh./ assoc. prof. PhD. arch.

cosmin.caciuc@gmail.com

Universitatea de Arhitectură şi Urbanism „Ion Mincu”, Bucureşti, RO/

„Ion Mincu” University of Architecture and Urbanism, Bucharest, RO

\begin{abstract}
Rezumat
Obiectivul cercetării urmărește reevaluarea și readucerea în atenția profesională a modelului european de practică urbană și arhitecturală, prea repede căzut însă în uitare, prin care locuirea colectivă în favoarea orașului a ocupat o poziție dominantă: Internationale Bauausstellung Berlin (IBA) 1987. Metodologia acestei reevaluări are la bază experiența concretă la amplasamentele berlineze din cadrul IBA in cadrul vizitelor mele recente, dar mai ales o cercetare istoriografică extinsă asupra publicisticii arhitecturale care a însoțit oficial evenimentul și concursurile sale de arhitectură. Am interpretat fenomenul arhitectural prin texte teoretice colaterale, relevante atât pentru o hermeneutică înzestrată cu capacitatea de slăbire
\end{abstract}

\begin{abstract}
The objective of this research aims to re-evaluate and bring again to the professional attention an European model of urban and architectural practice concerned with collective dwelling in favor of the city, too quickly fell into oblivion: Internationale Bauausstellung Berlin (IBA) 1987. The methodology of this reassessment is based on a concrete experience at IBA locations in Berlin during my recent visits there, followed by an extensive historiographic research on the architectural publications that officially accompanied the event and its architectural competitions. I have interpreted this architectural phenomenon through collateral theoretical texts, relevant both for a hermeneutic endowed with the capacity of
\end{abstract}


a cadrelor tari / scientiste de înțelegere a realității, cât și pentru ceea ce aș numi în sens mai larg o cartografie intelectuală pentru profesie, rememorând concepte antologice precum istoricismul, formalismul și post-funcționalismul cu scopul de a reveni la principiile locuirii colective pentru oraș, motivate de puterea evocatoare a reconstrucției urbane critice.

Mijlocul deceniului al șaptelea al secolului XX reprezintă un moment de turnură în teoria arhitecturii, prin care problematica locurii colective se desprinde de ideologia funcționalist-scientistă și de „Noua Obiectivitate” care a guvernat principiile raționale de reconstrucție postbelică în Europa occidentală. Între 1965 și 1987, o hermeneutică înspirată larg de filosofie s-a dezvoltat intens în critica de arhitectură, orientând-o către orizontul istoric și ideea de recuperare a orașului prin locuire. Neînțelegerea sau ignorarea mizei fundamentale a acestui interes la nivelul practicii curente ne face să recunoaștem acum, în contextul nostru local, prea puține exemple de bună practică a locuirii colective poziționate explicit în favoarea orașului.

Privirea interpretativă îndreptată către fenomenul IBA 1987, adresată cu precădere locuirii colective, ne pune în fața unor concluzii esențiale, relevante acum și la noi mai mult decât oricând: 1) reînnoirea urbană trebuie făcută prudent, pe fragmente, privind în mod analogic către precedentele istorice valoroase și abandonând discursul rudimentar al progresismului scientist sau futurist; 2) concepția arhitecturală se produce ca o consecință a înțelegerii tipologice a țesutului urban sedimentat istoric în care strada, piața și insula urbană sunt elementele morfologice constitutive în memoria colectivă; 3) weakening the scientific hard frames of understanding the reality, as well as for what I would call in a broader sense an intellectual cartography for our profession, recalling anthological concepts such as historicism, formalism and postfunctionalism in order to return to the principles of collective dwelling for the city, motivated by the evocative power of critical urban reconstruction.

The middle of the seventh decade of the twentieth century represents a turning point in the theory of architecture, whereby the issue of the collective dwelling deviates from the functionalistic-scientist ideology and the "New Objectivity" that governed the rational principles of post-war reconstruction in Western Europe. Between 1965 and 1987, a widelyinspired by philosophy hermeneutics intensely developed itself inside the critique of architecture, orienting it towards the historical horizon and the idea of recovering the city by dwelling. Misunderstanding or ignoring the fundamental stake of this interest in the current practice makes us now recognizing in our local context too few examples of good practice where collective dwelling is explicitly situated in favor of the city.

The interpretative approach concerning IBA 1987, mainly addressed to collective living, draws out some essential conclusions, which are now relevant to us more than ever: 1) urban renewal must be prudently done, by fragments, looking analogously to the valuable historical precedents and abandoning the rudimentary scientific discourse of progressism; 2) the architectural conception occurs as a consequence of the typological understanding of the historically settled urban tissue in which the street, the square and the urban island are the constitutive morphological elements inside a 
locuirea colectivă și spațiul public diferențiat nu pot fi disociate în demersul teoretic, realitatea concretă și experiența perceptuală a însușirii spațiului de către o comunitate. collective memory; 3) collective housing and differentiated public space can not be dissociated in the theoretical approach, concrete reality and perceptual experience of community space sharing.

\section{Cuvinte cheie/ Keywords}

hermeneutică, istoricism, formalism, post-funcționalism, locuire colectivă, reconstrucție urbană critică/ hermeneutics, historicism, formalism, post-functionalism, collective dwelling, critical urban reconstruction

\section{Preambul: hermeneutica „gândirii slabe”}

Vizitele recente la Berlin, pe amplasamentele Internationale Bauausstellung (IBA) 1987 și 1957 miau prilejuit un îndelung proces de reflecție, stimulat metodologic de cercetarea istoriografică ulterioară între rafturile bibliotecii, printre publicațiile care au descris în detaliu aceste evenimente și textele teoretice colaterale capabile să contureze un orizont intelectual mai larg pe tema locurii colective în contextul reconstrucției critice posteblice în Europa. Obiectivul cercetării constă în primul rând în atragerea atenției profesionale locale asupra operațiunii IBA 1987 ca model de bună practică, în contrast cu modelul IBA 1957 care a marcat un eșec evident al urbanismului modernist occidental după principiile interbelice ale Congreselor de Arhitectură Modernă (CIAM) dedicate în mod special locurii colective. lar acest obiectiv implică la un nivel mult mai profund o metodologie legată în mod direct de problema centrală a proiectării: sursa formelor arhitecturale care stă la baza metodelor de proiectare și la înțelegerea modului în care ideile de arhitectură pot fi exprimate coerent și responsabil în sfera publică. Pentru a identifica această sursă cu rădăcini ramificate este absolut necesară

\section{Preamble: "Weak Thought" Hermeneutics}

My recent visits to Berlin, on the Internationale Bauausstellung (IBA) 1987 and 1957 sites, engaged me into a long process of reflection, methodologically stimulated by subsequent historiographic research between the library shelves, among the publications that described in detail these events and the collateral theoretical texts capable of outline a broader intellectual horizon on the topic of collective dwelling in the context of urban reconstruction in Europe after 1945. The research objective is primarily to draw local professional attention to the 1987 IBA operation as a good model of practice, in contrast to the 1957 IBA exhibition, which marked an obvious failure of Western modernist urbanism following the interwar principles of the Congresses of Modern Architecture (CIAM) dedicated to collective dwelling. And this objective implies at a much deeper level a methodology directly related to the central problem of architectural design: the source of architectural forms underlying at the project bases and inside the methods in which architectural ideas can be expressed coherently and responsibly in the public sphere. In order to identify this source 
aprofundarea culturii teoretice profesionale dezvoltată după 1965. Un filon teoretic s-a detașat în adâncimea filosofică a discursurilor diversificate, dovedindu-și remarcabila pertinență în timp: hermeneutica de orientare post-fenomenologică care a primit, la mijlocul anilor ' 80 , în școala italiană de gândire, prin personalitățile lui Gianni Vattimo și Pier Aldo Rovatti, eticheta "gândirii slabe" sau „ontologiei slabe” (Vattimo și Rovatti 1998). Metodologia, ca manieră de a gândi, a implicat în acest caz, cartografia intelectuală a unui orizont mai larg de practică culturală și teoretică, articulat cu un model de interpretare specific, descris filosofic de patru aspecte fundamentale: 1) recunoasterea sfârșitului structurilor stabile de gândire rațională prin care se fundamentează valorile culturale; 2) aprecierea în cadrul existenței a aspectelor discursive contextuale, a formelor simbolice multiple și a diversificării aparențelor estetice; 3) dezvoltarea gândirii capabile să depotenţeze raţionalitatea scientistă și ideologia progresistă propagate în mod necritic și universalist; 4) reformularea legăturii dintre existența umană și limbaj astfel încât privirea în trecut să regăsească tradițiile precedente de gândire și discursurile mai degrabă ca simple urme sau amintiri, demne de atenție tocmai prin această înțelegere slăbită și pioasă.

Prin urmare, sensul profund al slăbirii postfenomenologice se regăsește în conștientizarea lipsei unui proiect autentic în gândirea preocupată de critica radicală a tradițiilor. Reparcurgerea discursurilor anterioare ca o vizită erudită printr-un anticariat are motivația estetică a bucuriei retrăirii trecutului în propriul său orizont, ca o imersiune întrun mod uitat de viață sau ca o degustare de forme spirituale într-un muzeu cu intenția edificării with multiple roots, it is necessary to deepen the professional theoretical culture developed after 1965. A theoretical thread detached itself into the philosophical depth of the diversified discourses, proving its remarkable pertinence over time: the post-phenomenological hermeneutics which received the label of "weak thought" or "weak ontology" in the mid-1980s, in the Italian school of thought, through the personalities of Gianni Vattimo and Pier Aldo Rovatti (Vattimo and Rovatti 1998). The methodology, as a way of thinking, involved in this case, the intellectual cartography of a wider horizon of cultural and theoretical practice, articulated with a specific interpretation model, philosophically described by four fundamental aspects: 1) the recognition of the end of stable rational thinking structures through which cultural values are expressed; 2) the appreciation in our existence of contextual discursive aspects, multiple symbolic forms and aesthetic appearances; 3) the development of a thinking capable of slowing down the non-critical and universalist scientific rationality and progressive ideology; 4) re-articulating the link between human existence and language so that the look in the past can regain the previous traditions of thought and discourses rather as mere traces in time or memories, worthy of attention precisely through this weak and pious understanding.

Therefore, the profound meaning of postphenomenological weakening is found in the awareness of the lack of a genuine project in thinking concerned with the radical critique of traditions. Browsing again the previous discourses as an erudite visit through an antique shop has an aesthetic motivation for the joy of reliquing the past in its own horizon, as an immersion in a forgotten way of life or as a tasting spiritual forms in a museum 
hermeneutice a subiectului care privește înapoi în timp, prin filtre critice. Edificarea hermeneutică implică și o slăbire a suveranității teoriei faţă de practică: teoretizarea urmează adesea retroactiv și întărește exemplele sociale și estetice de bună practică, nicidecum nu le determină de pe o poziție superioară.

\section{Post-funcționalism: „arhitectura slabă” și modelul berlinez al reconstrucției critice}

Într-un eseu antologic, Gianni Vattimo și-a îndreptat atenția în mod explicit spre arhitectură, remarcând schimbarea condiției actuale a profesiei noastre și a planificării orașului (Vattimo 1997). Recunoașterea eșecului privirii de sus în jos exercitate de către arhitecții-planificatori motivați de ideologia inaugural-demiurgică a modernismului propulsat de raționalismul tehnic coboară proiectantul acum pe o poziție mult mai modestă de operator estetic de simboluri. Doar în cadrul unei comunități specifice rolul arhitectului se precizează prin modul de comunicare socială, de implicare în discursurile de argumentare și chiar în formele retorice de persuasiune politică. Arhitectul devine în primul rând un intelectual critic și un mediator responsabil al valorilor culturale în proiect pentru a putea fixa într-un orizont mai larg premisele planului de arhitectură în contextul orașului. Legitimarea conceptuală a unui proiect nu se mai poate face acum în mod idealist sau materialist și nu are ca sprijin nici subiectivismul estetic și nici pretenția deterministă a obiectivității științifice specifice raționalismului legat ideologic de așa numita „Nouă Obiectivitate" (Frampton 2016, 148-154). with the intention of edifying the human subject looking back in time with critical filters. Hermeneutic edification implies a weakening of the sovereignty of theory to practice: the theorization often follows retrospectively and strengthens the social and aesthetic examples of good practice, but does not determine them from a superior position.

\section{Post-Functionalism: "Weak architecture" and the Berlin Model of Critical Reconstruction}

In an anthological essay, Gianni Vattimo explicitly turned his attention to architecture, remarking a change in the current condition of our profession and in the city planning (Vattimo 1997). Recognizing the failure of top-down view exerted by architects motivated only by the consciousness of their own genius and the inaugural-demiurgical ideology of modernity propelled by technical rationalism, the designer descends now on a more modest position of aesthetic operator of symbols. Only in a specific community the role of the architect is clarified by the way he/she proves capable of social communication, involvement in argumentation discourses and even in the rhetorical forms of political persuasion. The architect becomes first of all a critical intellectual and a responsible mediator of the cultural values in the project to be able to set the premises of the architectural plan in the context of the city and in a broader perspective. The conceptual legitimacy of a project can no longer be expressed in an idealistic or materialist way, and it supports neither the aesthetic subjectivism nor the deterministic claim of scientific objectivity specific to rationalism linked ideologically by the so-called 
Raționalitatea rigidă cu pretenții universale a caracterizat ediția Internationale Bauausstellung (IBA) Hansaviertel, Berlin, din 1957, în care se remarca cu precădere blocul de apartamente al lui Walter Gropius (Fig. 1), având în fundal ecourile ultimelor două ediții Congrès Internationaux d'Architecture Moderne (CIAM) de la Aix-enProvence (1953) și Dubrovnik (1956), înainte de dizolvare, în care s-a dezbătut problema locuirii prin corectarea funcționalismului reductivist. Cele mai severe efecte în sfera urbanismului au fost însă consființite în edițiile II-IV CIAM, între 1929-1933, când s-a căzut de acord la nivel profesional asupra nimicirii străzii-coridor tradiționale la sugestia explicită a lui Le Corbusier. Tot în aceste ediții interbelice s-au formulat principiile functionaliste Existenzminimum, directivele planificării raționale a orașului și conceptul orașului segregat la nivel funcțional. După 1945, principiile au fost puse în aplicare și testate la scară reală. Gândirea cu raționalitate rigidă $\mathrm{s}-\mathrm{a}$ sistematizat între funcționalismul ideologic și științific („Noua Obiectivitate"), istoricismul Zeitgeist (supunerea necondiționată față de spiritul timpului echivalat cu progresul prin tehnologie impus de sus în jos) și forma de arhitectură desprinsă față de oraș (prin eradicarea străzii tradiționale și a blocului urban construit perimetral). Chiar în anul inaugurării IBA Hansaviertel 1957, Konrad Wachsmann, unul dintre colaboratorii lui Walter Gropius, publica „Seven Theses" ca un rezumat edificator al raționalității rigide și universale de la baza modernismului: (1) stabilirea scopurilor arhitecturale de către știință și tehnologie; (2) ordinea socială produsă prin efectele tehnologiei; (3) acceptarea necondiționată a noilor materiale, tehnologii, tehnici de planificare și condiții sociale; (4) construirea derivată din
"New Objectivity" (Frampton 2016, 148-154).

Rigid rationality with universal pretensions featured the 1958 Internationale Bauausstellung (IBA) Hansaviertel, Berlin, where we remarked Walter Gropius's block of flats (Fig. 1), having in the background the echoes of the last two editions of the Congrès Internationaux d'Architecture Moderne (CIAM) in Aix-en-Provence (1953) and Dubrovnik (1956), before its dissolution, where the problem of habitation was debated by correcting the reductivist functionalism. The most severe effects in urban sphere were, however, created by CIAM II-IV, between 1929-1933, when it was agreed on a professional level on the destruction of the traditional corridor-street, following Le Corbusier's explicit suggestion. Also in these interwar editions the functional principles Existenzminimum were formulated together with the rational planning directives and the concept of functional segregated city. After 1945, these principles were implemented and tested on a real scale. The rigid rationality has been systematized by ideological and scientific functionalism (the "New Objectivity"), Zeitgeist historicism (unconditional obedience to the spirit of time equated with progress through top-down technology) and architecture detached from the city (through the eradication of the traditional street and perimetral built urban block). Even in the year of inaugurating the IBA Hansaviertel 1957, Konrad Wachsmann, one of Walter Gropius' collaborators, published "Seven Theses" as a summary of the rigid and universal rationality at the foundation of modernism: (1) the establishment of architectural goals by science and technology; (2) social order produced by the effects of technology; (3) unconditional acceptance of new materials, technologies, planning techniques and social 
industrializare; (5) gândirea creativă inflențată direct de știința experimentală și automatizare; (6) proiectarea realizată cu echipe de experți industriali; (7) idealurile umane și estetice aliniate fără compromisuri la noua cunoaștere contemporană și la abilitățile tehnice (Wachsmann 1957). conditions; (4) construction derived from industrialization; (5) creative thinking infused directly by experimental science and automation; (6) designing with teams of industrial experts; (7) the human and aesthetic ideals uncompromisingly aligned on new contemporary knowledge and technical abilities (Wachsmann 1957).

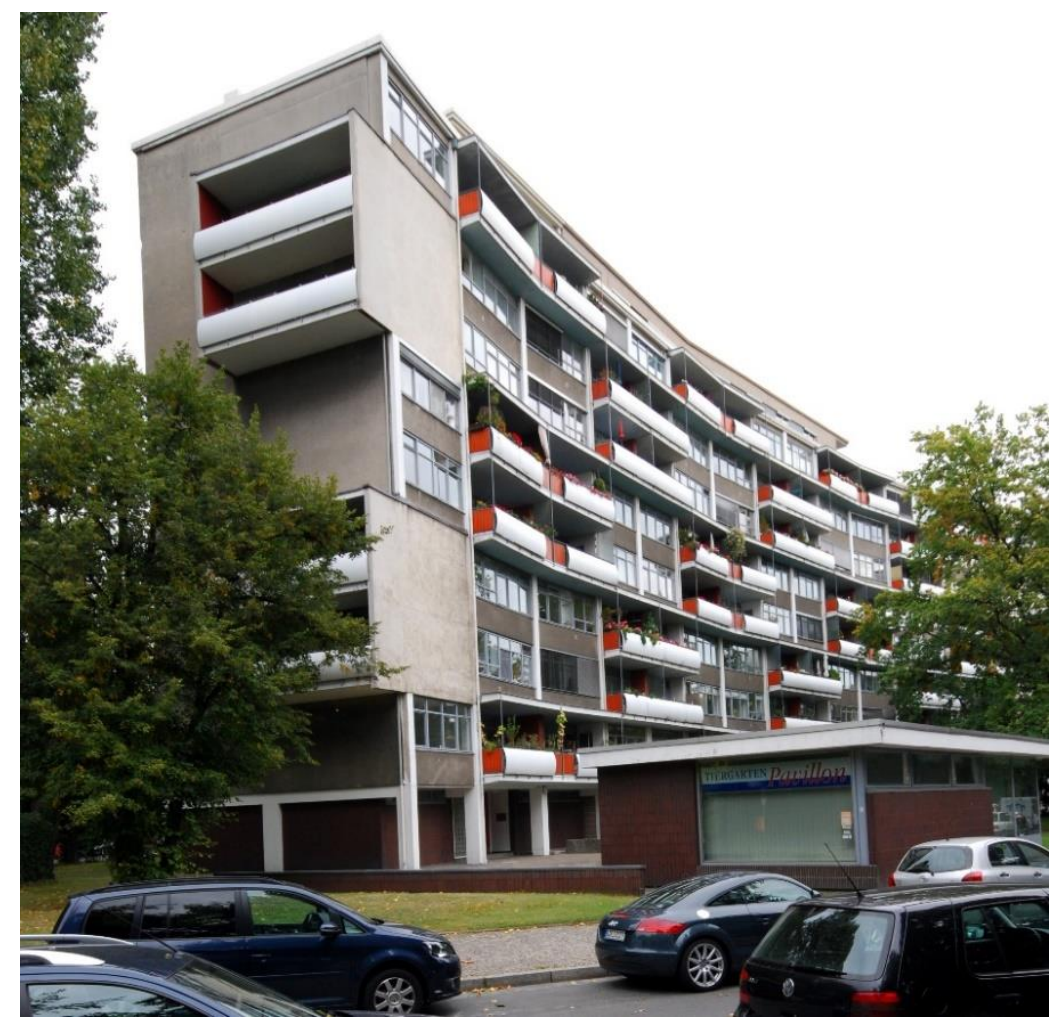

Fig. 1: Walter Gropius, bloc de apartamente în cadrul/ block of flats at Internationale Bauausstellung (IBA) Hansaviertel, Berlin, 1957 (c) Cosmin Caciuc 
Împotriva acestei raționalități limitative și nocive pentru locuirea urbană, teoreticianul catalan Ignasi de Solà-Morales preia în teoria arhitecturii sugestiile „gândirii slabe” italiene și le dezvoltă ca instrumente operative în critica adresată fenomenului arhitectural contemporan în eseul-manifest intitulat „Weak Architecture“ (de Solà-Morales 1987). În momentul în care ajungea la apogeu Internationale Bauausstellung (IBA) 1987, expoziția de arhitectură cu o largă participare internațională pentru reconstrucția Berlinului de Vest, eseul dedicat "arhitecturii slabe” identifică un pertinent model hermeneutic. Îl rezumăm în zece puncte: (1) deziluzionarea filosofică față de rațiunea puternică idealistă sau scientistă; sfârșitul istoriei liniare; (2) asimilarea critică în arhitectură a mijloacelor de produç̧ie modernă industrială; (3) modestia proiectantului exprimată printr-o atitudine etică față de loc și comunitate; (4) contextualism și intervenție prin fragmente; (5) cultură a construirii tectonice; (6) rigoare compoziţională / „mult cu puțin”; (7) acceptarea schimbării și efemerității; (8) atitudinea reținută față de căutarea noutății estetice ca scop în sine; (9) reparcurgerea critică a tradiţiei estetice moderniste; (10) privirea analogică către istorie, sincronismul similarităţii şi diferenţei. Pentru a defini mai clar orizontul hermeneutic al "gândirii slabe" răsfrânte către critica producției de arhitectură contemporane putem adăuga faptul că Ignasi de Solà-Morales Rubió a dezbătut anterior conceptul de analogie prin care înțelegem raportarea slăbită, dar profund semnificativă, a arhitecturii contemporane față de trecut (de Solà-Morales 1985).
Against this limited and harmful rationalism concerning urban dwelling, Catalan theorist Ignasi de Solà-Morales introduced in the architectural theory's the suggestions of Italian "weak thought" hermeneutics and developed them as operative tools for a criticism of the contemporary architectural phenomenon, in the manifesto essay entitled "Weak Architecture" (Solà-Morales 1987). At the time of the International Architecture Bauhausstellung (IBA) 1987, an architecture exhibition with a large international participation for the reconstruction of West Berlin, the essay dedicated to "weak architecture" identifies a pertinent hermeneutical model. We summarize it in ten points: (1) philosophical disillusionment with the strong idealistic or scientific reason; the end of linear history; (2) critical assimilation into the architecture of modern industrial production means; (3) the designer's modesty expressed in an ethical attitude towards place and community; (4) contextualism and fragmentation; (5) tectonic construction culture; (6) compositional rigor/ "more with less"; (7) acceptance of change and transience; (8) temperance of the pursuit of aesthetic novelty as an end in itself; (9) critical rethinking of the modernist aesthetic tradition; (10) an approach of history by analogy, understanding synchronicity of similarity and difference. In order to define more clearly the hermeneutical horizon of "weak thought" reflected in the criticism of contemporary architectural production, we can add that Ignasi de Solà-Morales Rubió previously discussed the concept of analogy by which we mean the fragile but profoundly significant relation of contemporary architecture to the past (Sol-Morales 1985). 
Acest fundal teoretic al post-funcționalismului poate fi în mod evident relaționat cu setul de principii directoare din cadrul IBA 1987, formulate de coordonatorii agenției urbane de dezvoltare, Josef Paul Kleihues și Hardt-Walt Hamer: (1) politică de reînnoire urbană prudentă; (2) reconstrucție critică a orașului; (3) laborator de proiectare urbană; (4) definirea străzilor și piețelor prin front construit; (5) participaționism în cartierele vulnerabile; (6) blocul urban construit perimetral - reevaluare critică; (7) reactivarea spațiului verde public (Kleihues și Klotz 1986, 7-12). Trebuie menționat și faptul că organizarea agenției a fost impulsionată de protestele publice din zona Kreutzberg, între 19791982, îndreptate împotriva modernizării urbane violente și demolărilor tabula rasa. Apoi, Berlinul de Vest beneficia de avantajul excepțional al subvenționării internaționale în sectorul locuințelor sociale și reconstrucției postbelice. Dincolo de aspectele organizatorice și economice, modelul arhitectural al reconstrucției blocului urban berlinez a fost reprezentat chiar de ansamblul rezidențial realizat de Paul Kleihues în Vinetaplatz, BerlinWedding, între 1971-77. Concepția arhitecturală a acestuia a rezultat din analogia istorică în raport cu țesutul urban antebelic, valorizând curțile interioare semipublice ale blocului urban, din care s-au eliminat volumele parazitare și extinderile necontrolate.

Masterplanul IBA 1987 generaliza modelul Vinetaplatz pentru întreg arealul istoric la sud de Parcul Tiergarten, însă acorda o flexibilitate tipologică insulelor urbane, astfel încât acestea să se evidențieze ca fragmente cu o identitate proprie. În plus, nu toate zonele supuse intervențiilor se puteau adapta la modelul reconstrucției simple a frontului la stradă. Cartierul Kreutzberg constituia o astfel de
Post-functionalism theoretical background can obviously be related to the IBA 1987 guiding principles formulated by the coordinators of this urban development agency, Josef Paul Kleihues and Hardt-Walt Hamer: (1) prudent urban renewal policy; (2) critical reconstruction of the city; (3) urban design laboratory; (4) defining streets and squares by building facades; (5) participationism in vulnerable neighborhoods; (6) perimeter built urban block - critical re-evaluation; (7) reactivation of the public green space (Kleihues and Klotz 1986, 7-12). It should also be mentioned that the organization of the agency was stimulated by the public protests in the Kreutzberg area, between 1979-1982, directed against violent urbanization and tabula rasa demolitions. West Berlin benefited then from the exceptional advantage of international subsidies in the social housing sector and post-war reconstruction. Beyond the organizational and economic aspects, the architectural model of Berlin urban block reconstruction was represented by the residential urban assembly of buildings designed by Paul Kleihues in Vinetaplatz, Berlin-Wedding, between 1971-77. Its architectural conception resulted from the historical analogy with the prewar urban fabric, valuing the semi-public inner courtyards of the urban block, from which the parasitic volumes and uncontrolled expansions were eliminated.

The IBA Masterplan 1987 generalized the Vinetaplatz model for the entire historic area south of the Tiergarten Park, but granted a typological flexibility to the urban blocks so that they would be highlighted as fragments with their own identity. In addition, not all intervention areas could be adapted to the simple front-to-street reconstruction model. Kreutzberg district was such a difficult area, and 
zonă dificilă, iar Alvaro Siza, arhitectul portughez invitatat în cadrul IBA 1987, a oferit un răspuns critic la principiile masterplanului lui Kleihues prin două proiecte exemplare: propunerea a 6 intervenții punctuale pentru aria Frankelufer (1979) și 3 intervenții în Blocul urban \#121 din Schelesisches Strasse (1980). În urma operațiunii din Schelesisches Strasse, desfășurată timp de opt ani, au rezultat blocul de apartamente cu 7 niveluri „Bonjour Tristesse" (Fig. 2), o grădiniță și un club de pensionari.
Alvaro Siza, the Portuguese architect invited to the IBA 1987, offered a critical response to the Kleihues' principles for his masterplan through two exemplary projects: the proposal of 6 small interventions for the Frankelufer area (1979) and 3 interventions in the urban block \#121 of Schelesisches Strasse (1980). The eight-year operation in Schelesisches Strasse resulted in a 7-level block of flats "Bonjour Tristesse" (Fig. 2), a kindergarten and a retirement club.

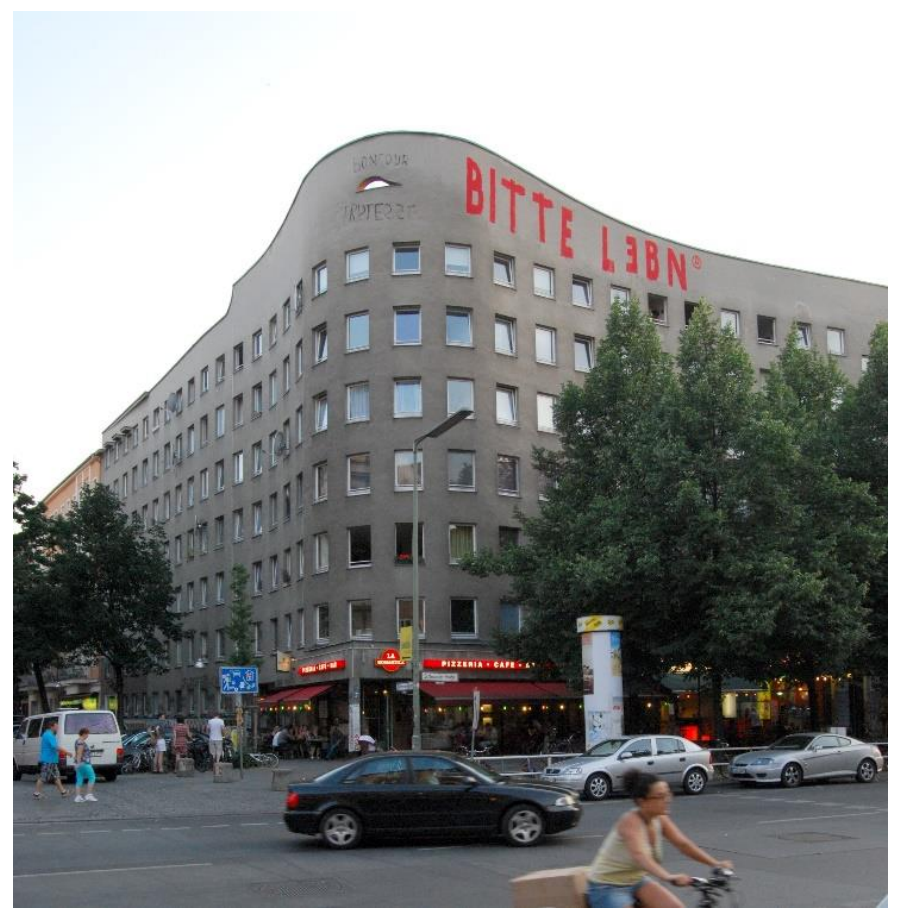

Fig. 2: Alvaro Siza, blocul de apartamente „Bonjour Tristesse” din/„Bonjour Tristesse” block of flats in Schelesisches Strasse, Berlin (1980) (c) Cosmin Caciuc 
Blocul „Bonjour Tristesse” atrage cel mai mult atenția dinspre stradă, însă nu trebuie privit ca un obiect de sine stătător și nici ca o simplă completare de front stradal, ci ca un fragment inserat printr-o strategie cu raționalitate slăbită în țesutul existent care a suportat deopotrivă condiția traumatică a distrugerii și cea a reconstrucției. Acest proiect exprimă o abordare contextuală critică inspirată de paradigma arhitecturii nedecorate, a „tăcerii civice”, inaugurată în 1911 de clădirea lui Adolf Loos din Michaelerplatz în Viena. Proiectele din Schelesisches Strasse și Frankelufer au atras după sine și o critică a reconstrucției integrale a blocului urban berlinez. Intervențiile s-au sprijinit atât pe interpretarea clivajului dintre raționalizarea fațadelor aliniate la stradă și aglomerarea curților în interiorul blocurilor urbane, cât și pe menținerea conflictelor formei urbane în interiorul proiectului. Astfel, s-au exprimat în acele soluții condiția interstițiilor din interiorul blocului urban, raportarea critică la principiul alinierii la stradă și la trama istorică, menținerea inflexiunilor volumetrice ale blocurilor astfel încât să reflecte particularitățile amplasamentelor, ferestrele mici, ierarhia verticală a fațadelor, similară elevațiilor istorice, parapetul opac la un atic înalt și atribuirea de funcțiuni semipublice la parterul clădirilor cu vitrine extinse până la nivelul pardoselii. Pentru Siza, raționalitatea slăbită presupune interpretarea realității existențiale a amplasamentului printr-o reculegere simbolică față de moștenirea trecutului și prin recursul la studiul tipologic astfel încât relaționarea urbană a clădirilor să se contopească cu memoria colectivă a locuitorilor.
The "Bonjour Tristesse" block attracts the most attention from the street, but it should not be seen as a standalone object, nor as a mere addition to the street front, but as a fragment embedded in the existing urban tissue that supported both the traumatic condition of the destruction and the reconstruction of the urban block, through a weakened rationality strategy. This project expresses a critical contextual approach inspired by the paradigm of undecorated architecture and "civic silence" inaugurated in 1911 by Adolf Loos's building in Michaelerplatz in Vienna. The projects in Schelesisches Strasse and Frankelufer have also involved a critique of the complete reconstruction of the Berlin urban block. Those interventions supported both the interpretation of the cleavage between the rationalization of street-faced facades and the agglomeration of the courtyards within the urban blocks as well as the maintenance of the urban conflicts within the project. Thus those solutions clearly expressed the interstitial condition inside the urban block, the critical approach to the principle of alignment to the historic streets grid, the maintenance of the volumetric inflections of the blocks so as to reflect the particularities of the sites, the small windows, the facades vertical hierarchy similar to the historical elevations, the opaque parapet at a high attic and the assignment of semipublic functions on the ground floor of the buildings with shop windows extended down to the level of the sidewalk. For Siza, weakened rationality implies the interpretation of the existential reality of the site through a symbolic collectedness over the legacy of the past and the typological study, so that the urban relationship of the buildings coincides with the collective memory of the inhabitants. 
Dacă Alvaro Siza poate fi considerat un exemplu favorit în spiritul „arhitecturii slabe” din manifestul teoretic al catalanului Ignasi de Solà-Morales menționat anterior, care s-a putut articula cu succes în programul IBA 1987, Peter Eisenman, de asemenea invitat să participe la acest program cu un proiect de concurs desfășurat între 1981-1984 pentru „epicentrul” expoziției, blocul Checkpoint Charlie (Fig. 3), a criticat în mod radical atât noțiunea lui Kleihues de reconstrucție istorică a blocului urban pe baze tipologice, cât și principiile metateoretice ale umanismului care susțin fundalul filosofic al acesteia.
If Alvaro Siza can be considered a favorite example in the spirit of "weak architecture" in Ignasi de SolàMorales' theoretical manifesto mentioned earlier, which was successfully articulated in the 1987 IBA program, Peter Eisenman also invited to participate in this program with a competition project conducted between 1981-1984 for the "epicenter" of the exhibition, the Ceckpoint Charlie block (Fig. 3), radically criticized Kleihues' notion of urban block historic reconstruction on typological bases, as well as metateoretical principles of humanism that philosophically support the reconstruction background.

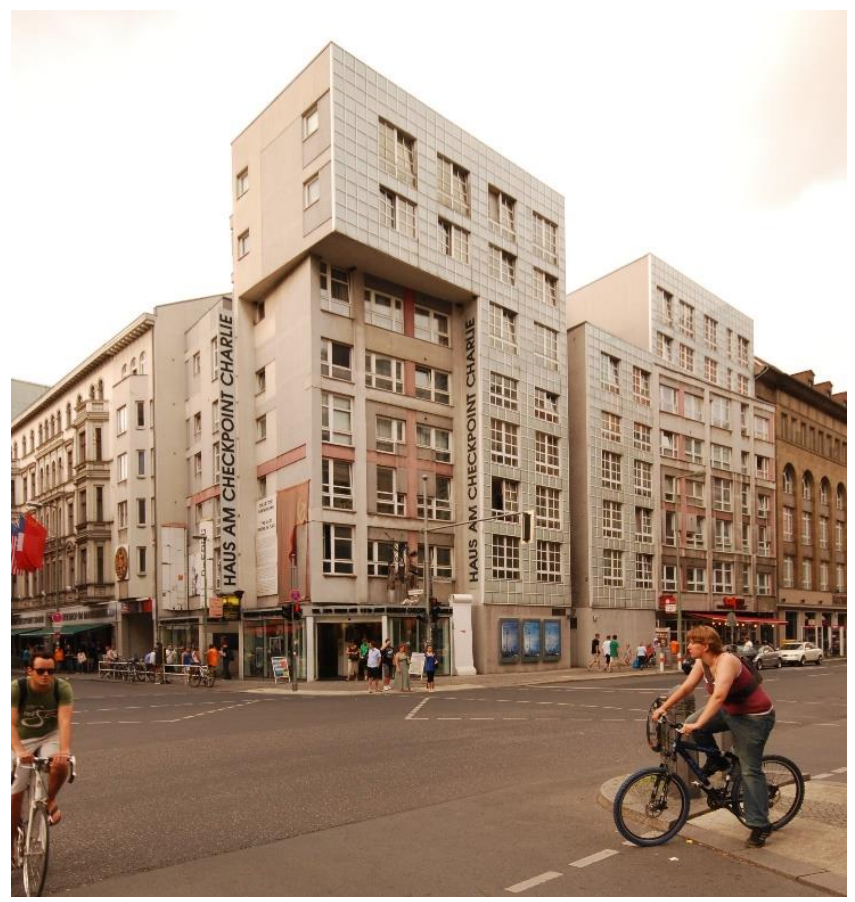

Fig. 3: Peter Eisenman, blocul Checkpoint Charlie/Checkpoint Charlie block of flats Kochstrasse / Friedrichstrasse, Berlin (1981-1984) (c) Cosmin Caciuc 
Într-un articol publicat în 1976, dezvolta în mod explict conceptul de post-funcționalism prin anunțul celor trei "sfârșituri" în arhitectură, inspirat de filosofia poststructuralistă franceză (Eisenman, 1976): (1) sfârșitul umanismului dezantropomorfizarea arhitecturii; (2) sfârșitul dezvoltării liniare a istoriei în formula hegeliană abandonul determinării arhitecturii printr-un „spirit al timpului"; (3) sfârșitul arhitecturii funcționaliste în care forma este determinată prin știință și tehnologie. De fapt, Eisenman anunța că modernismul autentic nici nu a fost până în acel moment elaborat în arhitectură, de vreme ce Mișcarea Modernă interbelică nu se desprinsese teoretic față de umanism, „spiritul timpului” și determinările venite dinspre știință și tehnologie. Din acel moment, modernismul doar ca deconstrucție a metafizicii arhitecturii ar fi reprezentat ruptura radicală față de umanism, iar Eisenman „translata” deconstrucția direct în proiectul de pe amplasamentul Checkpoint Charlie printr-un exercițiu eminamente conceptual. Astfel, post-funcționalistmul în arhitectură implica dislocarea fragmentelor arhitecturale dintr-un întreg urban, desprinderea formei de semnificații, reducţia formei la un sistem sintactic de semne libere, atemporalitatea formei și mai ales deconstrucția explicită a raționalității formei.

În mod evident, noțiunea de post-funcționalism atinge aici o limită hermeneutică în contextul „gândirii slabe” care poate adresa o critică justificată deconstrucției. Performanța discursivă a lui Eisenman, strict ca proiect individual și ca autoconstrucție intelectuală, este absolut remarcabilă, însă ca proiect public de generalizare a
In an article published in 1976, he explicitly develops the concept of post-functionalism through the announcement of the three "ends" in architecture, inspired by French post-structural philosophy (Eisenman, 1976): (1) the end of humanism and anthropomorphism of architecture; (2) the end of the linear development of history in the Hegelian formula - abandoning the determination of architecture through a "spirit of time"; (3) the end of functionalist architecture in which form is determined by science and technology. In fact, Eisenman announced that authentic modernism was not even developed in architecture until then, since the Interwar Modern Movement had not theoretically detached itself from humanism, the "spirit of time," and the determinations of science and technology. From that moment, modernism only as a deconstruction of architecture metaphysics would have represented a radical departure from humanism, and Eisenman "translated" it directly into the project on the Checkpoint Charlie site through an extremely conceptual exercise. Thus, post-functionalism in architecture implies the dislocation of the architectural fragments from an urban whole, the separation between form and meaning, the reduction of the form to a syntactic system of free signs, the timeless nature of the form, and especially the explicit deconstruction of the form's rationality.

Obviously, the notion of post-functionalism reaches here a hermeneutical boundary in the context of "weak thinking" that can address a justified criticism to deconstruction. Eisenman's discursive performance, strictly as an individual project and as an intellectual self-construction, is absolutely remarkable, but as a public project to generalize the 
modelului gândirii deconstrucției în conștiința socială nu poate substitui în mod legitim nevoia colectivă de împărtășire facilă a unui orizont istoric și de recunoaștere fără piedici a unei continuități a istoriei. Din acest punct de vedere, nu credem că va conta prea mult dacă modernismul a fost sau nu cu adevărat elaborat în arhitectură ca dezantropomorfizare și destabilizare a fundațiilor metafizice. Modul cum interpretăm orizontul istoric astfel încât să fie capabil să edifice o colectivitate urbană și să se perpetueze critic într-o memorie colectivă este absolut esențial pentru o „gândire slabă".

\section{Istoricismul pietății: privirea recuperatoare în istorie}

Teoreticianul Alan Colquhoun identifică în practica anilor '80 trei tipuri de raportare arhitecturală la problema istoriei (Colquhoun 1983): 1) istoricismul modernist ca rupere violentă față de tradiții (în sensul avangardei); 2) istoricismul postmodernist ca preocupare și simpatie față de trecut (în sensul unei ariergarde) și 3) istoricismul ca postmodernism estetic figurativ în care istoria este o sursă neîngrădită de inspirație, iar stilurile trecutului, egal valorizate, sunt reinterpretate liber. În primul caz, este negată percepția clasicistă a valorilor și idealurilor atemporale. Emafaza unui „spirit al timpului" alimentat de tehnică și progres social căuta să se dezică de justificarea unor principii estetice pe baza unor legi fixe ale universului fizic sau principii raționale eterne. Urbanismul utopic de tip tabula rasa, cu argumentele științifice ale raționalizării industriale și igienei spațiului, destructurând principiul străzii-coridor, a survenit ca model of deconstruction thinking in social consciousness can not legitimately substitute the collective need for easy sharing of a historical horizon and continuity of history recognition without hindrance. From this point of view, we do not think it will matter much if modernism was or was not really elaborated in architecture as the end of antropomorphism and destabilization of metaphysical foundations. The way we interpret the historical horizon so as to be able to build an urban collectivity and to perpetuate itself critically in a collective memory is absolutely essential for a "weak thinking."

\section{Historicism of Piety: Revitalizing Perspective on History}

Theorist Alan Colquhoun identifies in the 1980s three types of architectural relations with history (Colquhoun 1983): 1) modernist historicism as a violent rupture of traditions (in the sense of avantgarde); 2) postmodernist historicism as a sympathy for the past (in the sense of an arierre-garde) and 3) historicism as a figurative aesthetic postmodernism in which history is an unlimited source of inspiration, and the styles of the past, equally valorized, are freely reinterpreted. In the first case, the classical perception of timeless ideals and values is denied. The emphasis of a "spirit of time" fueled by technical and social progress sought to deny the justification of aesthetic principles based on fixed laws of the physical universe or eternal rational principles. Utopian tabula rasa urbanization, engaging the scientific arguments of industrial rationalization and space hygiene, destroying the principle of the traditional corridor-street, has come about as a 
o consecință negativă a acestui mod de raportare disjunctă față de istorie.

Pe de altă parte, istoricismul postmodernist a recuperat privirea către trecut, însă nu a căzut de acord asupra modului în care interpretarea trebuie să discearnă între modele, locuri și moduri de a construi. Colqhoun operează mai intâi distincția între simpatia critică față de tradiții - pe care noi o vedem acum ca un atribut esențial al „gândirii slabe” -, și practica artistică militantă în favoarea relativismului cultural și mixajului de imagini istorice decupate de contextul lor originar, cu un scop ironic sau populist. El receptează cu încredere recuperarea tradițiilor, dar dezaprobă atât istoricismul determinist agregat simplist în jurul ideologiei progresului, cât și precedentul clasicist al obsesiei pentru idealism, legi universale, autoritate și rațiune, considerând în final tradiția ca pe o condiție necesară în trei direcții esențiale: 1) producția de semnificație arhitecturală; 2) interpretarea condiției urbane a prezentului; 3) internalizarea tradiției în arhitectura înțeleasă ca o disciplină autonomă care dispune de instrumente specifice ale cunoașterii realității. Toate aceste trei direcții sunt convergente cu modelul „gândirii slabe” care contestă modelul idealist al rațiunii clasice universale, determinismul istoric hegelian și relativismul cultural. Nu mai putem invoca azi o cultură pură și unificată pe care să o studiem cu pretenții de obiectivitate scientistă și să o folosim ca bază a consensului profesional; împrumuturile și schimburile culturale sunt esențiale pentru a regândi modul în care locuim în oraș; dispunem de mai multe raționalități. Nu avangarda este esențială în acest demers al obținerii consensului pe proiecte mult mai restrânse, ci ariergarda profesională alături de comunitatea implicată direct în proiectul respectiv în care se negative consequence of this disjunctive reference to history.

On the other hand, postmodernist historicism has returned to the past but did not agree on how interpretation should discern between models, places and ways to build. Colqhoun first operates the distinction between critical sympathy for tradition we now see it as a basic attribute of "weak thought" - and militant artistic practice in favor of cultural relativism and the mix of historical images detached from their original context for an ironic or populist purpose. He accepts with confidence the recovery of traditions, but disapproves of the deterministic historism simply aggregated around the ideology of progress, as well as the classicist precedent of obsession for idealism, universal laws, authority and reason, finally considering tradition as a necessary condition in three essential directions: 1) the production of architectural meaning; 2) the interpretation of the present urban condition; 3 ) the internalisation of tradition in architecture understood as an autonomous discipline that has specific knowledge of reality tools. All these three directions converge with the "weak thought" model that challenges the idealistic model of classical reason, Hegelian historical determinism and cultural relativism. We can no longer invoke today a pure and unified culture that we should study with the requirements of scientific objectivity and use it as a basis for professional consensus; cultural exchanges are essential to rethinking how we live in the city; we have more types of rationality. Not the avant-garde is essential in this approach to obtaining consensus on much more limited projects, but the professional arierre-garde with the community directly involved in the project in which a core of norms and patterns of living is emphasized. This conservative social 
evidențiază un nucleu păstrător de norme și de tipare ale locuirii. Acest nucleu social conservator poate energiza memoria culturală a colectivității în măsura în care nu procedează ideologic, în maniera eclecticilor în secolul al XIX-lea, folosind stilurile arhitecturale istorice drept embleme în reprezentarea unor idealuri.

Colqhoun apără arhitectura ca pe o formă a cunoașterii prin experiență, prin imersiune într-un mod de viață și nu doar ca o practică erudită prin care se pot manipula imagini și simboluri. Arhitectura nu poate transmite azi semnificații fixe și universale, iar trecutul nu se poate reintroduce în teoria actuală prin evacuarea tradiției moderniste. Interpretând exmplul IBA 1987 în acest cadru slăbit hermeneutic, vom decela două aspecte fundamentale ale apropierii față de istorie prin care ne putem detașa critic față de determinismul istoric: 1) opera de arhitectură nu este o reprezentare a unei idei de dinafara disciplinei (de sorginte socială, politică, artistică sau științifică), ci o practică autonomă care internalizează tradiții proprii și o memorie istorică ce solictă atât persistența tradițiilor prin repere estetice în actul proiectării, cât și transformarea normelor precedente; 2) teoria de arhitectură se preocupă de căutarea surselor primare ale formei arhitecturale, fără să izoleze disciplina noastră de alte discipline, tipologiile arhitecturale nefiind în totalitate determinate de condițiile materiale sau tehnice ale construirii.

În concluzie, nu vom căuta în cazul IBA 1987 noutatea avangardistă, idealismul politic și reprezentarea unei singure idei asupra progresului și emancipării sociale în locuire, ca în cazul IBA 1957, ci nucleus can energize the cultural memory of the collectivity insofar as it does not ideologically proceed in the eclectic manner in the nineteenth century, using historical architectural styles as emblems in representing ideals.

Colqhoun defends architecture as a form of knowledge through experience, as immersion in a way of life, and not just as an erudite practice through which images and symbols can be manipulated. Architecture can not convey today fixed and universal meanings, and the past can not be reintroduced into today's theory by evacuating the modernist tradition. By interpreting the IBA 1987 in this hermeneutically weakened context, we will note two fundamental aspects of the approach to history by which we can critically dissociate ourselves from historical determinism: 1) the architectural work is not a representation of an idea outside of the discipline (of social, political, artistic or scientific origin), but an autonomous practice that internalizes its own traditions and a historical memory which requests both the persistence of traditions by aesthetic references in the act of designing and the transformation of the previous norms; 2) architecture theory is concerned with the search for the primary sources of the architectural form, without isolating our discipline from other disciplines, the architectural typologies being not entirely determined by the material or technical conditions of the building.

In conclusion, we will not look for an avant-garde novelty, political idealism and the representation of a single idea of social progress and social emancipation in the IBA 1987 case, as in the IBA 
revelarea unei finitudini a arhitecturii în orizont istoric și contextual, printr-un filtru critic care nu mai poate invoca standarde universale de evaluare. IBA 1987 devine cel mult expresia unei experiențe a orașului prin locuire și analogie istorică care își generează autonom atât subiectul criticii, cât și instrumentele prin care se exercită critica. Vorbim de o arhitectură conștientă față de istorie, de un model al criticii prin proiect și de o experiență spațiului arhitectural prin locuirea colectivă.

\section{Formalism: analogie versus intertextualitate}

Evidențiem două sensuri ale formalismului în teoria arhitecturii contemporane. Primul sens, ca studiu comparativ al precedentelor clasice și moderniste cu scopul regăsirii unor structuri comune vizuale întrun orizont analogic, îl atribuim școlii neoraționalismului italian, reprezentate de Aldo Rossi după 1965 (Rossi 1982). Cel de al doilea sens se referă la modul în care Peter Eisenman ia în considerare forma ca un simplu "text”, urmărind discursul deconstrucției în arhitectură și criticând în mod evident abordarea analogică italiană (Eisenman 1976). Proiectele realizate de Aldo Rossi și Peter Eisenman în cadrul operațiunii IBA 1987 sunt o consecință a dezbaterii teoretice asupra formei și semnificației ei urbane, desfășurată timp de peste două decenii înaintea evenimentului berlinez.

În primul sens precizat anterior, formalismul este atribuit preocupărilor predilecte ale teoriei și practicii de arhitectură asupra autonomiei formei după critica funcționalismului, adăugate evidențierii unei tranziții de la principiile arhitecturii clasice la cele moderniste pe baza unor elemente structurale comune, în contextul rezistenţei profesionale
1957, but the revelation of a finitude of architecture in the historical and contextual horizon through a critical filter that can no longer invoke universal evaluation standards. The IBA 1987 is at most the expression of an experience of the city through dwelling and historical analogy that autonomously generates both the subject of criticism and the tools by which criticism is exercised. We are talking about an architecture conscious of history, a model of criticism through the project, and an experience of architectural space through collective dwelling.

\section{Formalism: analogy versus intertextuality}

We highlight two meanings of formalism in the theory of contemporary architecture. The first meaning, as a comparative study of classical and modernist precedents with the aim of finding common visual structures by analogy, is attributed to the school of Italian neo-rationalism, represented by Aldo Rossi after 1965 (Rossi 1982). The second meaning relates to how Peter Eisenman considers form as a simple "text", following the discourse of deconstruction in architecture and criticizing the Italian analogical approach (Eisenman 1976). The projects carried out by Aldo Rossi and Peter Eisenman in the IBA 1987 are a consequence of this theoretical debate on form and its urban significance, carried out over two decades before the Berlin event.

In the first sense, formalism is attributed to the preoccupations of the theory and practice of architecture on the autonomy of form after the criticism against functionalism, added to the emphasis of a transition from the principles of classical architecture to modernist ones based on structural elements common to both traditions in 
contra-ideologice faţă de societatea de consum (Scolari 1973). Studiul tipologic devenea o operaţie de clasificare capabilă să producă obiecte specifice disciplinei arhitecturii, care permit accesul cunoașterii noastre asupra convenţiilor, condiţiilor și limitelor arhitecturii. La Aldo Rossi, orașul este înțeles ca arhitectură (ca sumă a tuturor arhitecturilor lui diferite), iar arhitectura ca o construire a orașului în timp. Arhitectura este un fapt colectiv înainte de a fi creativ și conferă formă concretă societății, reflectând conștiința și memoria colectivă. Funcțiunea este efemeră, deci mult mai puțin importantă decât persistența artefactelor urbane și arhetipurilor: strada, piața și blocul urban construit perimetral. Noțiunea de permanență a structurilor urbane implică în mod necesar și conceptul de memorie colectivă ca ghid legitim de citire a structurii orașului. Arhitectura este pentru prima oară vazută ca un construct al memoriei colective. Tipul este o structură analitică folosită pentru a opera în miezul istoriei, identificând elementele autentice care există înaintea formelor de arhitectură. Din acest moment, tipologia catalizează formele noi între utopia modernistă și realitatea umanistă / clasică; aceasta operează deopotrivă ca proces de proiectare și ca obiect al proiectării, nemaifiind doar o simplă clasificare. Transformarea tipurilor e reținută în memoria colectivă și se detașează de metanarațiunea oficială a istoriei. Analogia nu implică nici ideea de progres și nici aceea de nostalgie istoricistă. Ea suspendă limitele spațiale și temporale, permițând noi asociații de imagini astfel încât să transforme orașul real într-o altă realitate psihologică, pe principiul „dislocării" vizuale a locurilor recognoscibile în memoria colectivă (ca în tablourile lui Canaletto din secolul al XVIII-lea) sau a scării arhitecturale (ca în the context of professional counter-ideological resistance to the consumer society (Scolari 1973). The typological study became a classification operation capable of producing objects specific to the discipline of architecture, allowing our knowledge to access the conventions, conditions and limits of architecture. At Aldo Rossi, the city is understood as architecture (as a sum of all its different architectures), and architecture as a city built in time. Architecture is a collective fact before being a creative action and confers concrete form to society, reflecting consciousness and collective memory. The function is ephemeral, therefore much less important than the persistence of urban artefacts and especially archetypes: the street, the square and the perimeter built urban block. The notion of urban structures permanence necessarily implies the concept of collective memory as a legitimate guide of reading the city's structure. Architecture is for the first time seen as a construct of collective memory. The type is an analytical structure used to operate in the core of history, identifying the authentic elements that exist before the forms of architecture. From this point on, the typology catalyses the new forms between the modernist utopia and the humanistic / classical reality; it operates both as a design process and as an object of design, not just a simple classification. The transformation of the types is retained in the collective memory and is detached from the official metanarration of history. The analogy does not imply either the idea of progress or the historicist nostalgia. It suspends spatial and temporal boundaries, allowing new image associations to turn the real city into another psychological reality, on the principle of visual "dislocation" of recognizable places in collective memory (as in Canaletto's 18th- 
viziunea renascentistă lui Leon Battista Alberti asupra casei ca un oraș și a orașului ca o casă). Între tipologiile fundamentale ale locuirii, vila urbană, locuința înșiruită și blocul de apartamente cu înălțime medie ocupă locul central. Ele sunt relaționate cu configurația blocului urban construit perimetral ca element fundamental al orașului istoric european. Sunt evidențiate cu predilecție în scoala neoraționalismului italian blocurile colective berlineze cu curți semideschise, tipologia pariziană hôtel particulier cu curți interioare și planul Cerdá pentru Barcelona, reprezentative pentru viziunea urbană din sec. al XIX-lea. Acesta este contextul în care Aldo Rossi realizează în cadrul IBA 1987 atât vila urbană din ansamblul Rauchstrasse pe baza masterplanului lui Rob Krier din 1980, cât și Blocul \#10 din zona Friedrichstadt Sud, Wilhelmstrasse / Kochstrasse, între 1981-1988 (Fig. 4). Acest din urmă proiect exemplifică ideea înțelegerii orașului ca prolog în proiect, strada fiind elementul generator: reconstituirea frontului Friedichstrasse.

Așa cum precizam anterior cu referire la proiectul de pe amplasamentul Checkpoint Charlie din cadrul IBA 1987, Peter Eisenman a criticat demersul neoraționalismului italian bazat pe analogia formală în orizontul continuității istorice și pe legătura dintre formele de arhitectură și semnificațiile lor transmise într-o memorie colectivă. Discursul său poststructuralist debutează cu propria teză de doctorat, The Formal Bases of Modern Architecture, century paintings) or shifting the architectural scale (as in Leon's Battista Alberti's Renaissance analogy of a house to a city and of a city to a house). Between the basic typologies of dwelling, the urban villa, the terraced houses and the block of flats with medium height occupy the central place. They are related to the configuration of the urban block with built perimeter as a fundamental element of the European historic city. In the school of Italian neorationalism, the collective dwelling with semi-open courtyards in Berlin, the Parisian typology of hôtel particulier with inner courtyards and Cerda masterplan for Barcelona are especially emphasized, as they are representative of the urban vision of the 19th century. Within the IBA 1987, this is the context in which Aldo Rossi realizes both the urban villa in the Rauchstrasse assembly of buildings on the basis of Rob Krier's master plan from 1980, and Block \#10 in the Friedrichstadt Sud area, Wilhelmstrasse / Kochstrasse, 1981-1988 (Fig. 4). This latter project exemplifies the idea of understanding the city as a prologue in the project, the street being the generating element: in this case, the reconstruction of the Friedichstrasse front.

As mentioned earlier with reference to IBA 1987 Checkpoint Charlie project, Peter Eisenman criticized the Italian neo-rationalism based on formal analogy in the horizon of historical continuity and the link between the architectural forms and their meanings transmitted in a collective memory. His post-structuralist discourse begins with his own doctoral thesis, The Formal Bases of Modern Architecture, presented in 1963 at the University of 


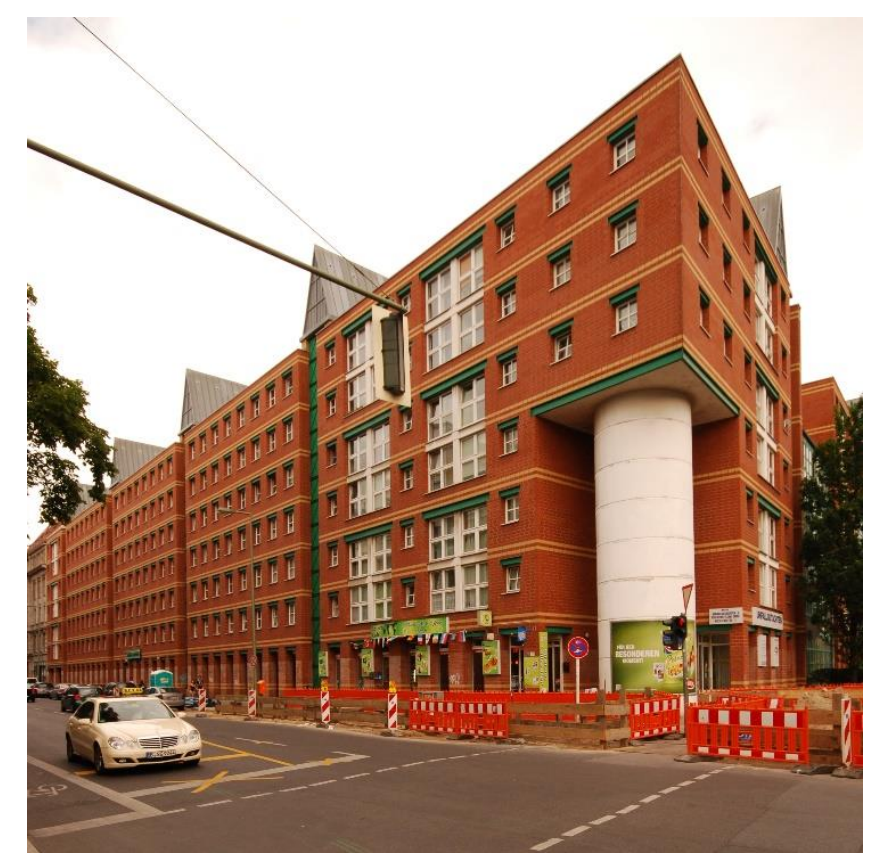

Fig. 4: Aldo Rossi, Blocul 10 din zona Friedrichstadt Sud/Block no. 10, Friedrichstadt South Wilhelmstrasse / Kochstrasse (1981-1988) (c) Cosmin Caciuc

susținută în 1963 la University of Cambridge sub îndrumarea lui Colin Rowe și republicată în facsimil în 2006 (Eisenman 2006 [1963]). Cercetarea sa se baza pe prioritatea formei în arhitectură și pe „gramatica” limbajului modernist de arhitectură. Proiectarea devine în consecință un proces conceptual autonom legat de un sistem formal activat de forțe interne, deformări și transformări care acționează asupra geometriilor primare și ideale, astfel încât să rezulte volumetrii arhitecturale specifice. Eisenman suspendă problematica semanticii în arhitectură (semnificația semnelor) și se concentrează exclusiv pe sintaxă (combinarea semnelor într-o strategie de proiectare). Nouă ani
Cambridge under the guidance of Colin Rowe and republished in facsimile in 2006 (Eisenman 2006 [1963]). His research was based on the priority of form in architecture and on the "grammar" of Modernist language of architecture. Designing therefore becomes an autonomous conceptual process linked to a formally activated system of internal forces, deformations and transformations that act on the primary and ideal geometries, so as to result in specific architectural volumes. Eisenman suspends the problem of semantics in architecture (sign meaning) and focuses exclusively on syntax (the combination of signs in a design strategy). Nine years later, he developed a post-functionalist 
mai târziu, dezvoltă un model teoretic pentru arhitectura post-funcționalistă în articolul „Cardboard Architecture", atribuind arhitecturii o preocupare exclusiv conceptuală (Eisenman 1972). În acest demers, se porneşte de la un volum generic / ideal şi de la o ordine spațială bazată pe grila regulată, însă ordinea inițială este deturnată de reguli sintactice ulterioare (manipulări geometrice complexe) cu motivații autonome și arbitrare care nu se justifică prin semnificații istorice. „Funcțiunea” și „structura” rămân doar niște noțiuni tolerate în interiorul formei, obiectivul proiectului fiind procesul de proiectare în sine ca o critică faţă de normele, valorile şi canoanele traditiilor moderne şi clasice. Acesta este sensul „arhitecturii de carton” pe care noi îl recunoaștem și în aspectul final al proiectului Checkpoint Charlie.

Comparând discursul lui Aldo Rossi cu cel al lui Peter Eisenman asupra chestiunii formalismului în arhitectură, remarcăm că în cazul lui Eisenman arhitectura se dezvăluie doar ca absență a conținutului colectiv și ca joc formal privat, inspirat de tehnicile moderne artistice, abstracte și radicale, fondate pe manipularea geometriei cu motivații filosofice eminamente poststructuraliste, a căror relevanță urbană este extrem de limitată. Eisenman critică neo-raționalismul italian pentru adeziunea sa la tradiția umanistă a împărtășirii semnificațiilor arhitecturii într-o memorie colectivă, dar desprinde efectiv arhitectura de oraș, reducând-o la o stratificare de texte fictive și trasformând-o într-un joc de limbaj privat, savant și autonom. La Rossi, formalismul este înțeles ca o evaluare morală, pronunțare etică și declarație de intenție în raport cu semnificațiile istorice, ca o expresie a unei judecăți asupra arhitecturii, orașului, istoriei și condiției profesionale, pe baza unor scopuri precise: theoretical model in an article entitled "Cardboard Architecture", attributing building to an exclusively conceptual concern (Eisenman 1972). This approach starts from a generic / ideal volume and from a regular order based on a grid, but the initial order is distorted by subsequent syntactical rules (complex geometrical manipulations) with autonomous and arbitrary motivations that are not justified by historical significance. The "function" and "structure" remain only some tolerable notions inside that form, the aim of the project being the design process itself as a critique of the norms, values and canons of modern and classical traditions. This is the meaning of "cardboard architecture" that we also recognize in the final look of the Checkpoint Charlie project.

Comparing Aldo Rossi's and Peter Eisenman's discourses on formalism in architecture, we note that in Eiseman's case architecture is revealed only as an absence of collective content and as a formal private game inspired by modern artistic, abstract and radical techniques based on the manipulation of geometry with eminently post-structuralist philosophical motivations, whose urban relevance is extremely limited. Eisenman criticizes Italian neorationalism for his adherence to the humanist tradition of sharing the meanings of architecture in a collective memory, but actually he separates architecture from the city reducing it to a stratification of fictional texts and transforming it into an independent private language. At Rossi, formalism is understood as a moral assessment, ethical pronouncement and statement of intent in relation to historical significance, as an expression of a judgment on architecture, city, history and professional condition, based on specific purposes: 
continuitatea orașului istoric (semnificativ) și legătura posibilă cu orașul contemporan (neadecvat și superficial).

\section{Concluzii}

IBA 1987 apare ca un model neepuizat până azi în ceea ce privește reconstrucția critică a orașului, raportarea acestuia la istorie și articularea unei culturi a construirii inspirate de raționalitatea slăbită, hibridizările conceptuale și strategiile multiplicate în interesul continuităților urbane. Noțiunea de raționalism poetic este potrivită pentru o astfel de abordare care a caracterizat cel mai bine strategia de proiectare a lui Josef Paul Kleihues (Fig. $5)$.

Aceasta reprezintă o cultură a arhitecturii moderne care, în primul rând, reevaluează valoroasa tradiție franceză academistă, respinsă de Mișcarea Modernă interbelică: Julien David Le Roy (1724-1803) - studiile asupra arhitecturii antice în Atena; Jean-NicolasLouis Durand (1760-1834) - neoclasicism; PierreFrançois-Henri Labrouste (1801-1875) - raționalism Beaux-Artes; Eugène Emmanuel Viollet-le-Duc (1814-1879) - formă și tehnologie modernă. În al doilea rând, apreciem influența italiană a Școlii de la Veneția și analiza tipologică a structurii urbane pe baza straturilor istorice, pe care Aldo Rossi a formulat-o exemplar în opera sa teoretică și în proiecte specifice. Prin coordonarea vastei operațiuni internaționale din Berlin sub deviza „reconstrucției critice”, Kleihues a propus dialogul arhitecturii moderne cu istoria locului și o abordare urbanistică de sinteză tipologică și rațională. A criticat triada modernistă funcțiune-economiestandardizare și a continuat pe de altă parte tradiția raționalistă care își dezvoltă reflecția din propriile the continuity of the historic city (meaningful) and the possible connection with the contemporary city (inadequate and superficial).

\section{Conclusions}

The IBA 1987 appears as an inexhaustible model until today for the critical reconstruction of the city, the relation with history and the articulation of a building culture inspired by weakened rationality, conceptual hybridizations and multiplied strategies in the interest of urban continuity. The notion of poetic rationalism is suitable for such an approach that has best characterized the design strategy of Josef Paul Kleihues (Fig. 5).

This represents a culture of modern architecture which, first of all, re-evaluates the valuable academic Beaux Artes French tradition rejected by the Interwar Modern Movement: Julien David Le Roy (1724-1803) - studies on ancient architecture in Athens; Jean-Nicolas-Louis Durand (1760-1834) Neoclassicism; Pierre-François-Henri Labrouste (1801-1875) - Beaux-Artes rationalism; Eugène Emmanuel Viollet-le-Duc (1814-1879) - modern form and technology. Secondly, we appreciate the Italian influence of the Venice School and the urban structure typological analysis based on historical layers, which Aldo Rossi formulated as an example in his theoretical work and specific projects. By coordinating the vast international operation in Berlin under the motto of "critical reconstruction," Kleihues proposed the dialogue of modern architecture with the history of the place and a typological and rational urbanistic approach. He criticized the modernist triad function-economystandardization and continued on the other hand 
principii disciplinare. Astfel, memoria istorică a devenit principalul concept critic îndreptat împotriva principiilor urbanistice promovate de Mișcarea Modernă prin edițiile interbelice ale CIAM. the rationalist tradition that develops its reflexivity from its own disciplinary principles. Thus, historical memory became the main critical concept against urbanistic principles promoted by the Modern Movement through CIAM's interwar editions.

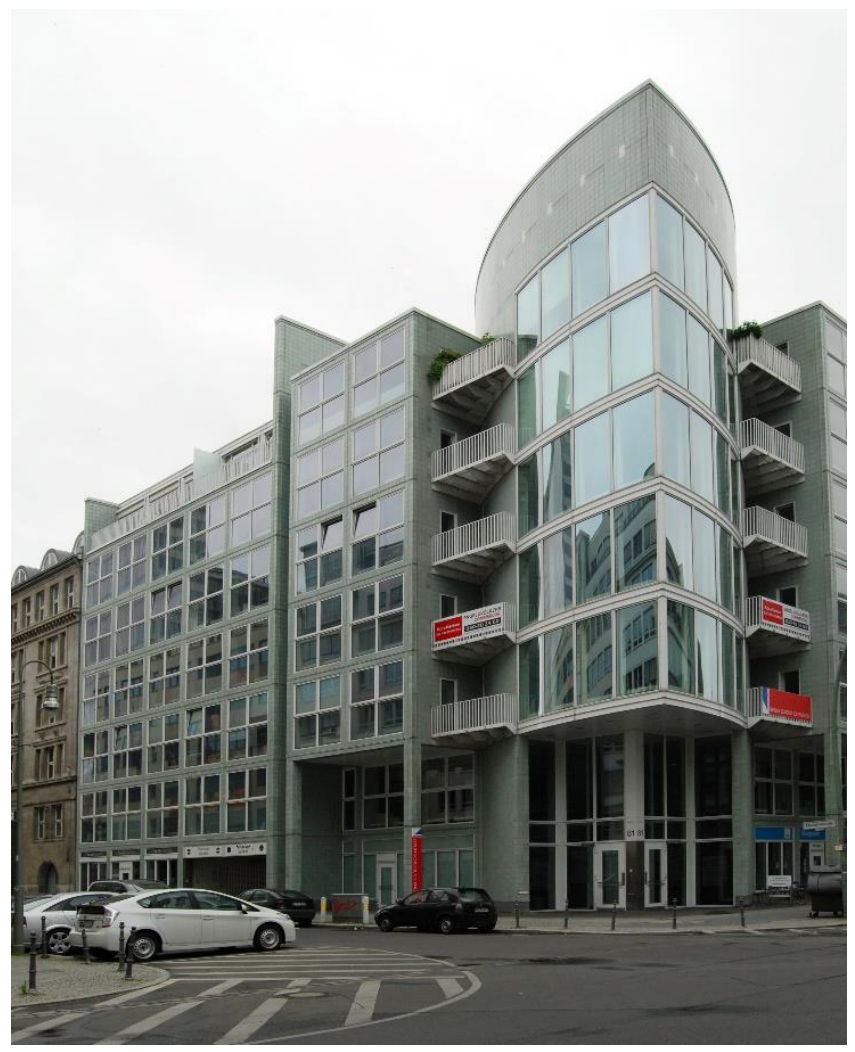

Fig. 5: J. P. Kleihues, Ansamblu de locuințe și birouri în blocul urban \#5/ Dwellings and offices development in urban block \#5

IBA 1987, Friedrichstrasse 45, Zimmerstrasse 23, Charlottenstrasse 81, Berlin (1994-1996) (c) Cosmin Caciuc 
Locuirea colectivă deține un rol fundamental în structura urbană a orașului european. Kleihues și Rossi au demonstrat că tiparele fundamentale de locuire nu s-au modificat semnificativ în ultimele două secole și că diferențele sunt generate de climă, materiale și tehnici constructive disponibile. Operațiunea IBA 1987 poate fi considerată ca o alternativă la IBA 1957 prin modelele sustenabile de creștere a densității, amestecul funcțional și tipologiile istorice recognoscibile. Aici locuirea colectivă s-a legat de înțelegerea spiritului unui loc constituit din stratificările de urme, indicii și discursuri peste un amplasament. A pornit de la lectura atentă a locurilor și de la evidențierea calității acestora, presupunând și o critică a codurilor și regulamentelor existente. Locurile au fost transformate prin prezența obiectelor de arhitectură. Locuirea colectivă s-a putut împleti cu o percepție poetică, având un rol corectiv și calitativ față de argumentarea rațională, normativă și cantitativă. Kleihues a acceptat o lume cu mai multe perspective asupra realității, diversitatea estetică, înțelegând și paradoxul „schimbării" orașului, păstrându-i continuitatea structurală. Interpretând exemple precum blocul Vinetaplatz și blocul \#10 din zona Friedrichstadt Sud, Wilhelmstrasse / Kochstrasse, putem afirma că raționalismul poetic oferă baza pentru o teorie capabilă să medieze pertinent între modernitate și istorie.

Acceptând acest model al ariergardei ca practică reflexivă, bazată pe memoria culturală colectivă, vom înțelege că reînnoirea urbană prin locuire colectivă are mai mult de câștigat din perspectiva „gândirii slabe" dacă abandonează discursul rudimentar al progresismului scientist sau futurist,
Collective dwelling has a fundamental role in the urban structure of the European city. Kleihues and Rossi have shown that fundamental patterns of habitation have not changed significantly over the last two centuries and that differences are generated by climate, materials and available construction techniques. The IBA 1987 operation can be considered as an alternative to the IBA 1957 through sustainable densification patterns, functional mixture and recognizable historical typologies. Here the collective living was related to an understanding of the spirit of a place consisting of the stratification of traces, clues and discourses over a site. It started from the careful reading of the places and the highlighting of their quality, assuming a critique of the existing codes and regulations. Places have been transformed by the presence of architectural objects. Collective dwelling could be intertwined with a poetic perception having a corrective and qualitative role in the rational, normative and quantitative argumentation. Kleihues accepted a world with multiple perspectives on reality, the aesthetic diversity, and also understood the paradox of "changing" the city, maintaining its structural continuity. Therefore, interpreting examples such as the Vinetaplatz block and Block \# 10 in the Friedrichstadt Sud area, Wilhelmstrasse / Kochstrasse, we can say that poetic rationality provides the basis for a theory capable of pertinent mediation between modernity and history.

By accepting this arierre-garde model as a reflexive practice based on collective cultural memory, we will understand that urban regeneration through collective dwelling has more to gain from the prospect of "weak thought" if it abandons the rudimentary discourse of scientific or futurist 
abordând prudent fragmentul urban în relație cu orașul, implicând analogia cu precedentele istorice valoroase, abordând tipologic țesutul urban sedimentat istoric și asociind permanent habitatului uman o rezervă de spațiu public diferențiat. progressism, prudently addressing the urban fragment in relation with the city, involving analogy with valuable historical precedents, approaching by typology the historically layered urban structure and permanently associating a differentiated public space to human habitat.

\section{Referinţe/ References}

Colquhoun A. (1983). Three Kinds of Historicism. In K. Nesbitt (Ed.), (1996), Theorizing a New Agenda for Architecture: An Anthology of Architectural Theory 1965 - 1995 (pp. 200-209). New York: Princeton Architectural Press.

de Solà-Morales, I. (1985). From Contrast to Analogy. In K. Nesbitt (Ed.), (1996), Theorizing a New Agenda for Architecture: An Anthology of Architectural Theory 1965 - 1995 (pp. 230-237). New York: Princeton Architectural Press. de Solà-Morales, I. (1987). Weak Architecture. In K. M. Hays (Ed.), (1998), Architectural Theory Since 1968 (pp. 616 623). Cambridge, MA: MIT Press.

Eisenman, P. (1976). Post-Functionalism. In K. Nesbitt (Ed.), (1996), Theorizing a New Agenda for Architecture: An Anthology of Architectural Theory 1965 - 1995 (pp. 80-83). New York: Princeton Architectural Press.

Eisenman, P. (1972). Cardboard Architecture. In C. Jencks \& K. Kropf (Eds.), (1997), Theories and Manifestoes of Contemporary Architecture (pp. 241-243). London: Academy Editions.

Eisenman, P. (2006 [1963]). The Formal Bases of Modern Architecture. Baden: Lars Müller Publishers.

Frampton, K., (2016). Arhitectura modernă. O istorie critică [Modern Architecture. A Critical History]. (M. Teodorescu, Trans.). Bucharest: Ed. Universitară „Ion Mincu”.

Kleihues, J. P. and Klotz H. (Eds.). (1986). Internationale Bauausstellung Berlin 1987. Beispiele einer neuen Architektur. Stuttgart: Klett-Cotta.

Rossi A. (1982). The Architecture of the City., (D. Ghirardo \& J. Ockman, Transl.). Cambridge Mass.: The MIT Press. Scolari M. (1973). The New Architecture and the Avant-Garde. In K. M. Hays (Ed.), (1998), Architectural Theory Since 1968 (pp. 114-122). Cambridge, MA: MIT Press.

Vattimo, G. (1997). The End of Modernity, the End of the Project?. In N. Leach (Ed.), Rethinking Architecture: A reader in Cultural Theory (pp.148-154). London: Routledge.

Vattimo, G. și Rovatti, P. A. (Ed.). (1998). Gândirea slabă [Weak Thought]. (̧̧. Mincu, Transl.). Constanţa: Pontica. Wachsmann K. (1957). Seven Theses. In W. Braham și J. A. Hale (Eds.), (2007), Rethinking Technology. A Reader in Architectural Theory (pp. 127-128). London: Routledge. 